\title{
Webbing Barklouse, Psocid (unofficial common names), Archipsocus nomas Gurney (Insecta: Psocoptera: Archipsocidae) $)^{1}$
}

Donald W. Hall and Jerry F. Butler ${ }^{2}$

\section{Introduction}

Archipsocus nomas Gurney is a communal web-spinning barklouse. During some years they make extensive silken webs that often cover the trunks and branches of trees in the southeastern U.S. The webs are believed to protect the barklice from predators. The webs are unsightly, but neither the barklice nor the webs cause any harm to the trees.

\section{Distribution}

Webbing barklice are found along the Gulf coast from Texas to Florida and along the Atlantic coast north to South Carolina.

\section{Description}

The eggs of A. nomas are oblong and wider at one end and gray or white in color. Nymphs and adults are soft-bodied insects with chewing mouthparts and long filamentous antennae. They lack cerci. First instar nymphs have eight antennal segments, but the full complement of 13 segments is gained at the first molt. The number of nymphal instars has not been determined for A. nomas. In Archipsocus floridanus, a closely related species, females have six, and males may have from four to six -- but most commonly five. Adults are darker in color than nymphs. When winged, the wings are membranous and held roof-like over the body. Winged females may be either long or short winged. Winged males are short winged.

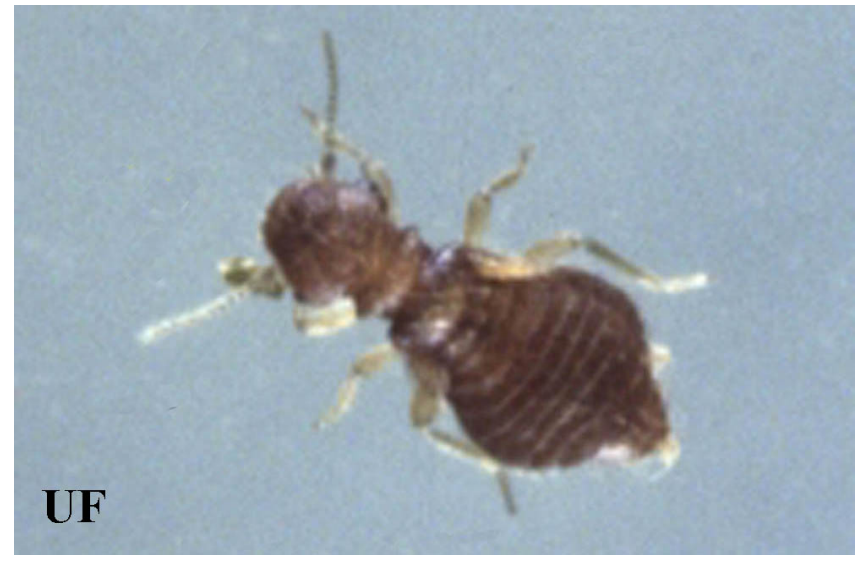

Figure 1. Young Archipsocus nomas Gurney nymph. Credits: J. F. Butler, University of Florida

1. This document is EENY-275, one of a series of Featured Creatures from the Entomology and Nematology Department, Florida Cooperative Extension Service, Institute of Food and Agricultural Sciences, University of Florida. Published: October 2002. This document is also available on Featured Creatures Website at http://creatures.ifas.ufl.edu. Please visit the EDIS Website at http://edis.ifas.ufl.edu.

2. Donald W. Hall and Jerry F. Butler, Entomology and Nematology Department, Institute of Food and Agricultural Sciences, University of Florida, Gainesville, FL 32611.

The Institute of Food and Agricultural Sciences (IFAS) is an Equal Employment Opportunity - Affirmative Action Employer authorized to provide research, educational information and other services only to individuals and institutions that function without regard to race, creed, color, religion, age, disability, sex, sexual orientation, marital status, national origin, political opinions or affiliations. For information on obtaining other extension publications, contact your county Cooperative Extension Service office. Florida Cooperative Extension Service / Institute of Food and Agricultural Sciences / University of Florida / Larry R. Arrington, Interim Dean 


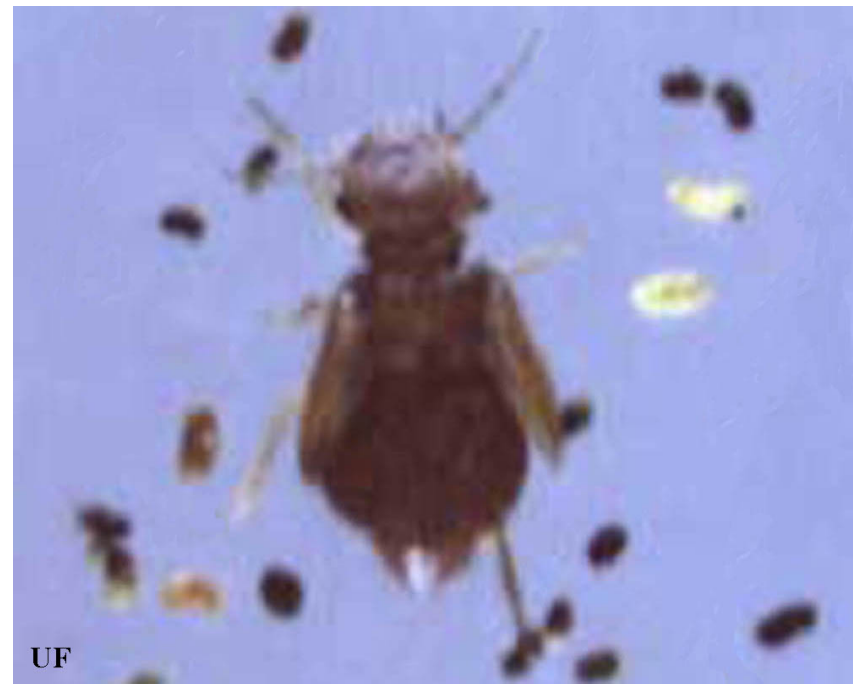

Figure 2. A late instar Archipsocus nomas Gurney nymph. Credits: J.F. Butler, University of Florida

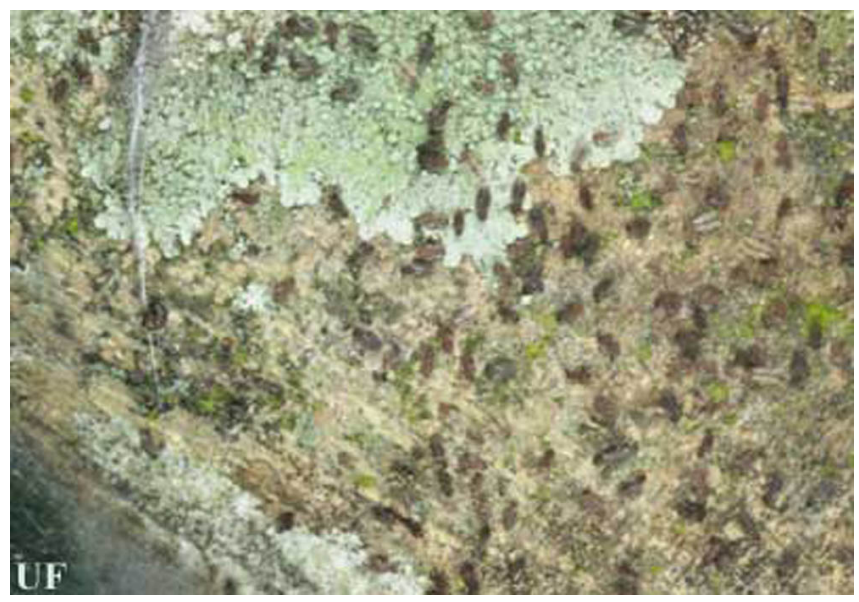

Figure 3. Archipsocus nomas Gurney winged females. Credits: D.W. Hall, University of Florida

\section{Life Cycle and Biology}

Colonies of A. nomas are rare during the winter (December-February in central Florida) and are concentrated in live oak (Quercus virginiana Mill.) hammocks and stands of cabbage palms (Sabal palmetto [Walter]) where they probably are best sheltered from killing frosts. During this time, colonies are composed primarily of adults with a few late instar nymphs. In the spring, eggs are laid singly or in groups and covered with debris or sometimes by feces. From March to June, colonies become more frequent, and from July to October, colonies rapidly increase in both number and size. The long-winged females are usually observed only during this time of maximum colony proliferation. Nymphs and adults probably feed primarily on lichens. By early
December, populations have been greatly reduced by frost, and the webs begin to disintegrate due to weathering. Because the barklice are not harmful, control measures are not recommended.

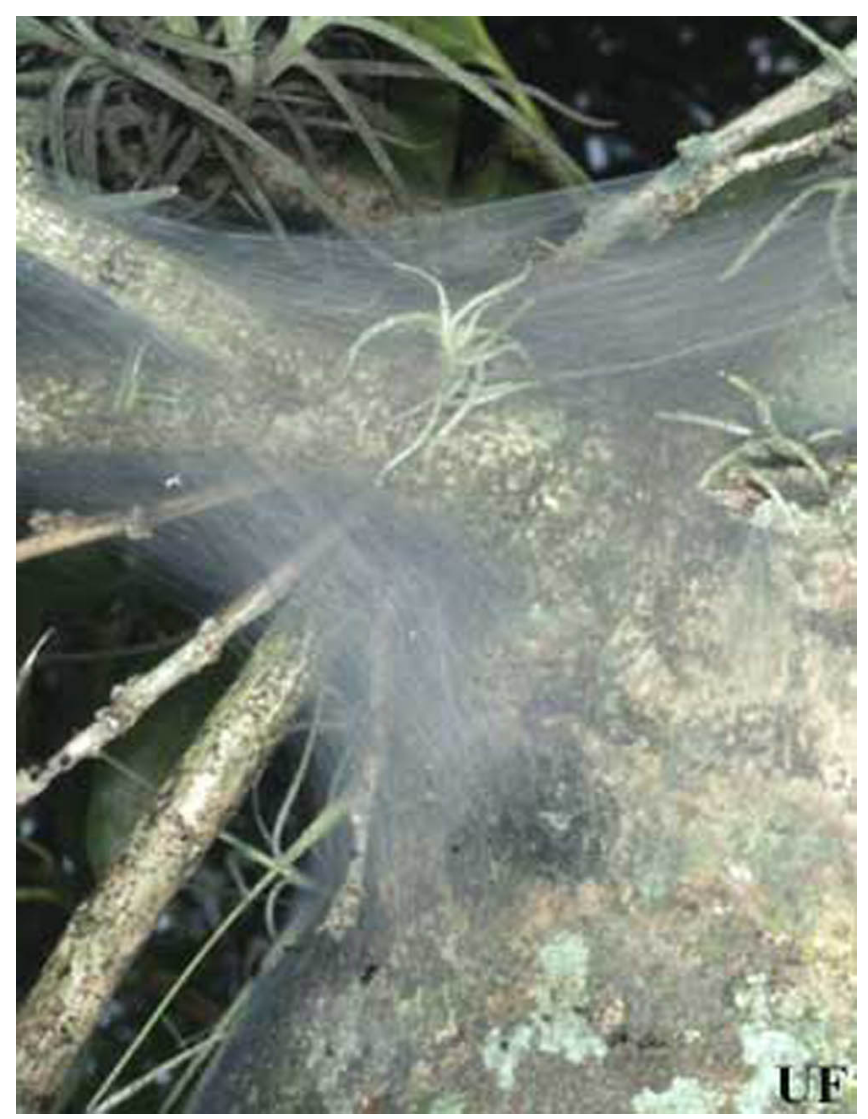

Figure 4. A late instar Archipsocus nomas Gurney nymph. Credits: D.W. Hall, University of Florida

\section{Selected References}

Borror DJ, Triplehorn CA, Johnson NF. 1989. An Introduction to the Study of Insects. Saunders College Publishing. Philadelphia

Mockford EL. 1953. Three new species of Archipsocus from Florida (Psocoptera: Archipsocidae). Florida Entomologist 26: 113-124.

Mockford EL. 1957. Life history studies on some Florida insects of the genus Archipsocus (Psocoptera). Bulletin of the Florida State Museum (Biological Sciences) University of Florida, Gainesville. 1: 253-274.

Mockford EL. 1987. Order Psocoptera. In: Stehr FW, ed., Immature Insects. (Vol. 1) Kendall/Hunt Publishing Company, Dubuque, Iowa. pp. 196-214. 


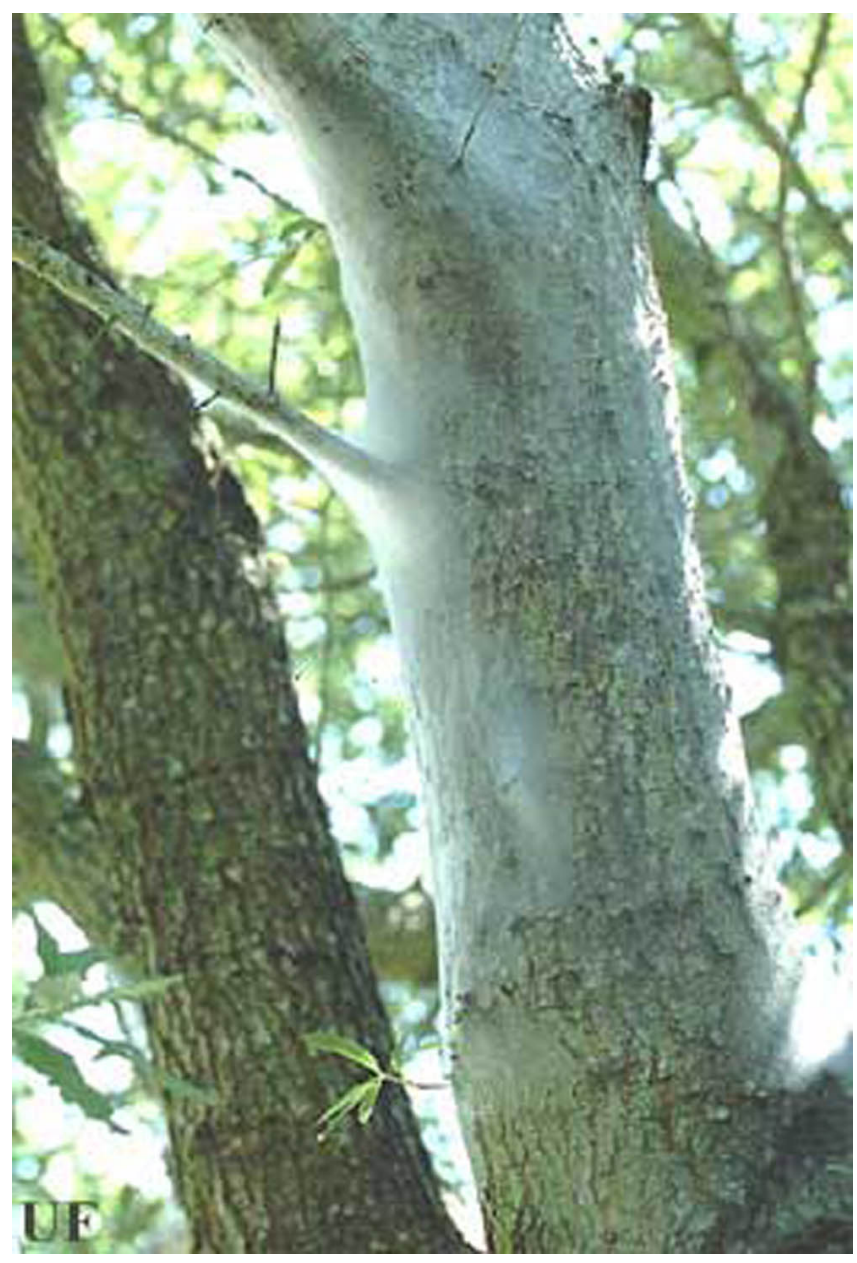

Figure 5. Tree trunk covered in webbing produced by Archipsocus nomas Gurney. Credits: Douglas L. Caldwell, University of Florida 